\title{
Role of the $\sigma^{70}$ subunit of RNA polymerase in transcriptional activation by activator protein $\mathrm{PhoB}$ in Escherichia coli
}

\author{
Kozo Makino, ${ }^{1}$ Mitsuko Amemura, Soo-Ki Kim, Atsuo Nakata, and Hideo Shinagawa \\ Department of Experimental Chemotherapy, Research Institute for Microbial Diseases, Osaka University, Osaka 565, Japan
}

\begin{abstract}
Transcription of the genes belonging to the phosphate $(p h o)$ regulon in Escherichia coli, which are induced by phosphate starvation, requires the specific activator protein PhoB in addition to the RNA polymerase holoenzyme containing the major $\sigma$-factor $\sigma^{70}$. To study the mechanism of transcriptional activation and identify the subunit of RNA polymerase involved in specific interaction with PhoB, we attempted to isolate $r p o A$ and $r p o D$ mutants that are specifically defective in the expression of the pho genes. We isolated two rpoD mutants with such properties, but no $r p o A$ mutant with similar properties. The rpoD mutations altered amino acids within and near the first helix of the putative helix-turn-helix (HTH) motif in the carboxy-terminal region of $\sigma^{70}$. Activities of the pho promoters in vivo were severely reduced in these mutants, whereas those of the PhoB-independent promoters were affected only marginally at most. The reconstituted mutant RNA polymerase holoenzymes were severely defective in transcribing the pst $S$ gene, one of the pho genes, whereas they were efficient in transcribing the PhoB-independent promoters. Phosphorylated PhoB, which binds to the pho promoters with high affinity, mediated the specific binding of the wild-type holoenzyme to the pstS promoter, but it did not mediate the binding of the mutant holoenzymes. These results suggest that PhoB promotes specific interaction between RNA polymerase and the pho promoters for transcriptional activation, and the first helix of the putative HTH motif plays an essential role in the interaction, probably by making direct contact with PhoB.
\end{abstract}

[Key Words: RNA polymerase; $\sigma^{70}$; phosphate regulon; $\mathrm{PhoB}$; $p s t S$ promoter]

Received September 9, 1992; revised version accepted November 10, 1992.

More than 30 genes in Escherichia coli including phoA, phoE, pstS, and ugpB, which are related to the transport and assimilation of phosphate, belong to the phosphate (pho) regulon. These genes are induced by phosphate starvation and require $\mathrm{PhoB}$ protein for their transcription. PhoB protein must be phosphorylated by PhoR protein to be active (Makino et al. 1989). The activity of PhoR in turn is regulated by the gene products in the pst-phoU operon, which sense phosphate levels in the medium and transduce the signal to PhoR by mechanisms still unknown (for reviews, see Nakata et al. 1987; Shinagawa et al. 1987).

The pho promoters contain functional -10 sequences (Kimura et al. 1989) but lack the consensus -35 sequence. They share the conserved 18 -bp sequence called the pho box, located $10 \mathrm{bp}$ upstream from the -10 sequence (Fig. 1; Makino et al. 1986). They contain at least one unit of the pho box, and some pho genes such as pstS and ugpB have two and three pho boxes tandemly re-

\footnotetext{
${ }^{1}$ Corresponding author.
}

peated, respectively (Kimura et al. 1989; Kasahara et al. 1991). Deletion analysis of these promoter regions also indicated that the pho box proximal to the -10 region is required for the expression of these genes. PhoB protein specifically binds to the pho box (Makino et al. 1986), and its affinity for the pho box increases upon phosphorylation (Makino et al. 1989). Transcription initiated from the pho promoters also requires the RNA polymerase holoenzyme containing $\sigma^{70}$, which is encoded by rpoD (Makino et al. 1988). However, we could not detect the binding of the holoenzyme to the pho promoters in the absence of phosphorylated PhoB protein under conditions that we could detect the binding of the holoenzyme to the tac and lac promoters (K. Makino, M. Amemura, H. Shinagawa, and A. Nakata, unpubl.). From these results and observations, we postulated that $\mathrm{PhoB}$ specifically interacts with one of the RNA polymerase subunits to introduce the polymerase to the pho promoters for the activation of transcriptional initiation.

To identify the subunit of RNA polymerase involved in the specific interaction with $\mathrm{PhoB}$, we attempted to isolate rpo mutants that severely decrease the expression 
Figure 1. Nucleotide sequences of the tac, trp, mel, lac, phoE, pstS, phoA, ugp B, and $p h o K$ promoter regions used in this study. Expression of the tac, trp, mel, and lac genes is $\mathrm{PhoB}$ independent; expression of the phoE, pstS, phoA, ugpB, and phoK genes is PhoB dependent. (O) Transcription initiation sites. Basic promoter elements $(-10$ and -35 signals) are boxed. Nucleotide sequences homologous to the consensus CRP-binding site (de Crombrugghe et al. 1984) and the PhoB-binding site (pho box) (Makino et al. 1986) are indicated by inverted arrows and underlines, repectively. Plasmids containing these promoter regions are described in Table 2 and Materials and methods.

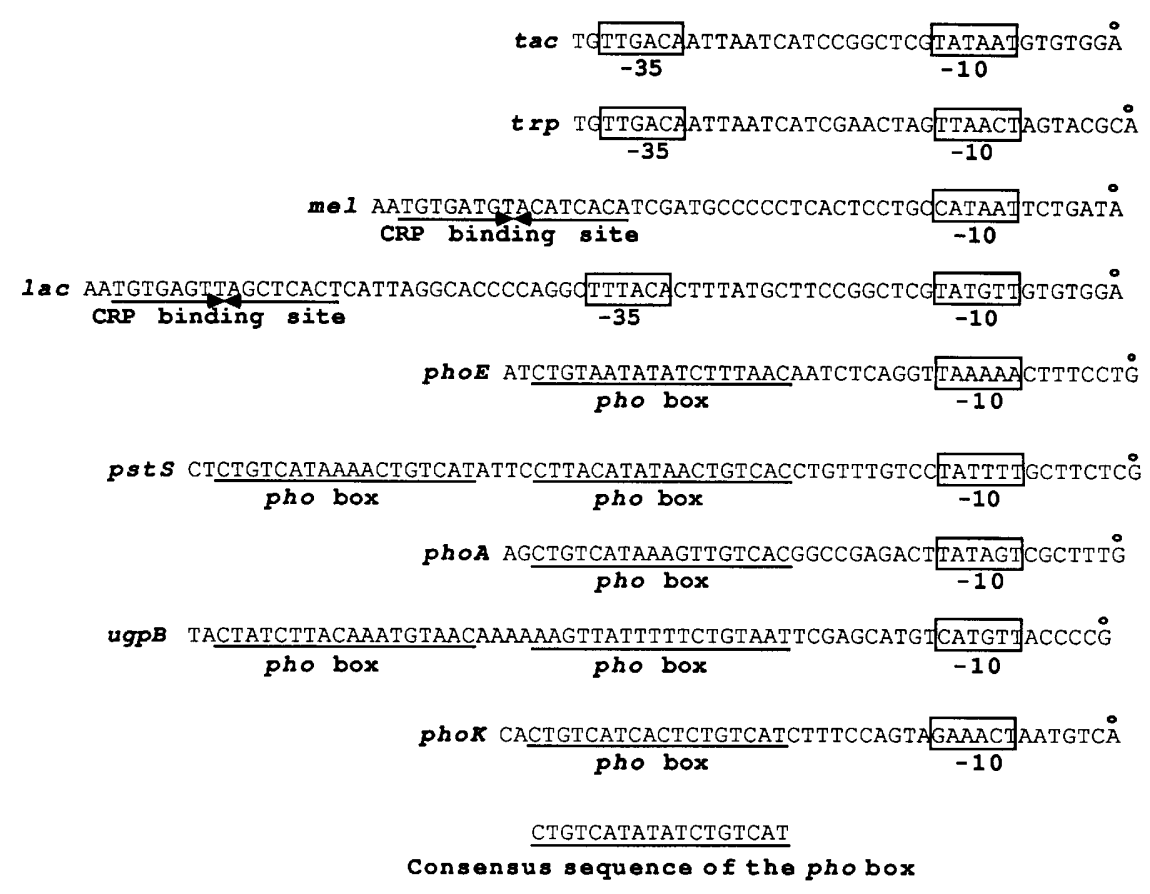

of the pho genes without causing a concomitant decrease in the expression of the majority of the other genes. Because several mutations in the gene encoding the $\alpha$-subunit of RNA polymerase $(r p o A)$ are defective in specific interactions with particular activator-dependent promoters (Garrett and Silhavy 1987; Matsuyama and Mizushima 1987; Lombardo et al. 1991; Slauch et al. 1991), we first sought, by localized mutagenesis, rpoA mutants defective in the interaction of RNA polymerase with the pho promoters. After failing to isolate such rpoA mutants, we looked for $r p o D$ mutants and succeeded in isolating mutants that could not specifically activate PhoBdependent transcription. The results obtained by in vivo and in vitro studies with the mutants and the products of the mutated genes support the hypothesis that PhoB interacts specifically with the $\sigma^{70}$ subunit of RNA polymerase, and this interaction facilitates the entry of the RNA polymerase into the pho promoters for transcription initiation.

\section{Results}

Isolation of $\mathrm{rpoD}$ mutants defective in the expression of pho genes

We tried to isolate $r p o D$ mutants encoding the altered $\sigma^{70}$ subunits that were defective in specific interaction with PhoB-dependent promoters. If PhoB regulates RNA polymerase activity by direct interaction with a specific region of the $\sigma^{70}$ subunit, it should be possible to isolate mutants in $r p o D$ that affect this interaction and specifically reduce expression of the pho genes. To test this hypothesis, we sought $r p o D$ mutations that decreased phoA expression in strain ANCC2, in which phoA expression is constitutive, with respect to phosphate con- centrations, and $p h o B$ dependent. We performed localized mutagenesis of the chromosome region containing $r p o D$ and screened for $r p o D$ mutants that decreased expression of alkaline phosphatase (APase) encoded by phoA. Strain CAG12152 contains a Tn10 insertion that is shown by $\mathrm{P} 1$ transduction to be $\sim 90 \%$ linked to $r p o D$ (Singer et al. 1989). P1 phage grown on a nitrosoguanidine-mutagenized strain, CAG12152, was used to transduce Tn10 (and closely linked rpoD) into ANCC2. After, the tetracycline-resistant colonies were selected, the transductant colonies were replicated on M9 glucose plates containing 5-bromo-4-chloro-3-indolyl phosphate (XP), a chromogenic substrate of APase, and the white colonies, which indicated decreased pho $A$ expression, were chosen for further analysis. Of 25,000 transductants, two mutants (ANCD75 and ANCD76), which showed the expected phenotype, were isolated. The levels of APase synthesis in these mutants were compared with those of wild-type and $p h o B$ deletion strains (Table 1). Similar to the phoB deletion strain, the ANCD $75 \mathrm{mu}-$ tant strain did not synthesize APase at all while the ANCD76 strain synthesized $\sim 3 \%$ as much APase as the wild-type strain. These mutations should not affect the expression of the housekeeping genes, as they formed similar sized colonies on Luria broth (LB) plates and grew as fast as the parent strain in LB and minimal media. The mutations that confer the $\mathrm{PhoA}^{-}$phenotype were $90 \%$ cotransduced with $\mathrm{Tn} 10$ by $\mathrm{P} 1$ transduction and, therefore, might be rpoD alleles.

We have also tried to isolate $r p o A$ mutants with lesions in the $\alpha$-subunit of RNA polymerase that severely decrease the expression of the pho genes specifically by a method described above. However, we could not obtain any $r p o A$ mutants with such a property even after screening 35,000 colonies. 
Table 1. APase activity in rpoD mutants

\begin{tabular}{lc}
\hline Host strain (relevant genotype) & APase activity $^{a}$ \\
\hline ANCD80 $\left(r p o D^{+}, p h o B^{+}\right)$ & 0.450 \\
ANCD75 $\left(r p o D 75, p h o B^{+}\right)$ & 0.003 \\
ANCD76 $\left(r p o D 76, p h o B^{+}\right)$ & 0.015 \\
ANCD801 $\left(r p o D^{+}, \Delta p h o B\right)$ & 0.002 \\
\hline
\end{tabular}

ane one-hundredth volume of the cultures grown overnight in $\mathrm{T}$-broth was inoculated into fresh M9 glucose medium. After 15 $\mathrm{hr}$ of incubation at $37^{\circ} \mathrm{C}$, APase activity was measured as described in Materials and methods. APase activity is expressed in micromoles of $p$-nitrophenol liberated per minute per $\mathrm{OD}_{540}$ unit of the culture. The data are the averages of three experiments.

\section{Cloning and sequencing of the mutant $\mathrm{rpoD}$ genes}

To identify by complementation assay the mutant alleles responsible for the decreased phoA expression, the mutants were transformed by a plasmid (pRW38) containing wild-type $r p o D$ and part of $d n a G$ from strain W3110. This plasmid complemented the defect in $p h o A$ expression of the ANCD75 and ANCD76 mutants (Fig. 2). Furthermore, plasmid pRW32 derived from pRW38, which lacks the $3^{\prime}$ region of the $r p o D$ gene, did not complement these mutations. These results show that the mutations in the $r p o D$ gene are responsible for the observed phenotypes. We cloned the $r p o D$ alleles from strains ANCD80 (rpoD $\left.{ }^{+}\right)$, ANCD75 (rpoD75), and ANCD76 (rpoD76) into the pUC18 vector. Plasmid pRP80 with the parental rpoD gene complemented these mutations while pRP75 and pRP76 with the mutant

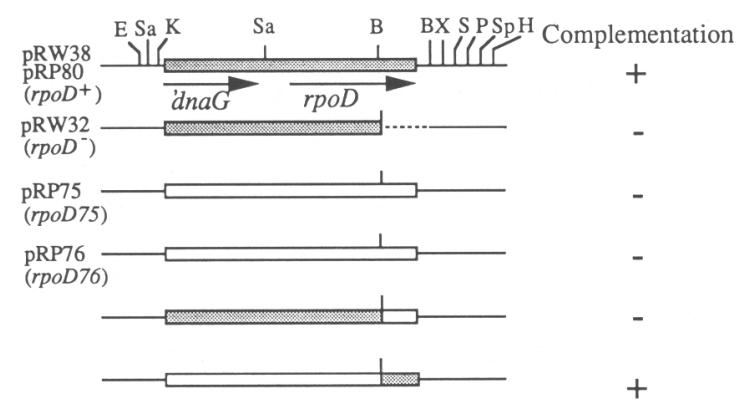

Figure 2. Complementation analysis of $r p o D$ mutations with cloned $r p o D$ alleles. The filled-in 3.8-kb EcoO109 fragments containing $r p o D$ and a part of $d n a G$ were cloned into the $S m a I$ site of pUC18 (Yanisch-Perron et al. 1985) as described in Materials and methods. The orientation and location of the truncated dnaG ('dnaG) and rpoD are indicated by arrows. Stretches of the pUC18 polylinker regions flanking the inserts are indicated by thin lines. The broken line indicates the deletion of the BamHI fragment. Shaded and open boxes indicate the DNA fragments of the $r p o D$ regions derived from the wild-type and APase negative strains, respectively. ANCD75 and ANCD76 strains were examined for complementation with the plasmids containing $r p o D$ alleles. Complementation was assayed on T-XP plates. Restriction sites: (E) EcoRI; (Sa) SacI; (K) KpnI; (B) BamHI; (X) XbaI; (S) SalI; (P) PstI; (Sp) SphI; (H) HindIII. rpo $D$ genes did not. To locate the mutation sites on the gene, we performed complementation analysis of the mutants with chimeric plasmids in which the smaller BamHI fragments that encode the carboxy-terminal region of the $\sigma^{70}$ subunit were exchanged between the wild-type and mutant genes, as shown in Figure 2. Because the hybrid $r p o D$ genes consisting of the $5^{\prime}$ region derived from the rpoD75 or rpoD76 allele and the $3^{\prime}$ region derived from the wild type complemented the rpoD75 and rpoD76 mutations, we concluded that the rpoD75 and rpoD76 mutation sites are located in the 0.6-kb BamHI fragment that encodes the carboxy-terminal region of the $\sigma^{70}$ subunit.

To identify the sequence alterations in the mutant alleles, we sequenced the DNA fragments carrying the wild-type and mutant $r p o D$ genes after recloning them from $\mathrm{pRP} 80$, $\mathrm{pRP75}$, and $\mathrm{pRP76}$ into the M13 phage vector mp18 (Yanisch-Perron et al. 1985). Entire regions of the genes were sequenced by using synthetic primers. The rpoD75 and rpoD76 alleles have transition mutations that result in changes of amino acids from Glu (GAA) to Lys (AAA) at residue 575 of $\sigma^{70}$ and from Asp (GAC) to Gly (GGC) at residue 570 , respectively. The amino acid change occurred within (RpoD75) or near (RpoD76) the first helix of the putative HTH motif in the carboxy-terminal region of $\sigma^{70}$ (Fig. 3). Because no sequence changes other than those described above were

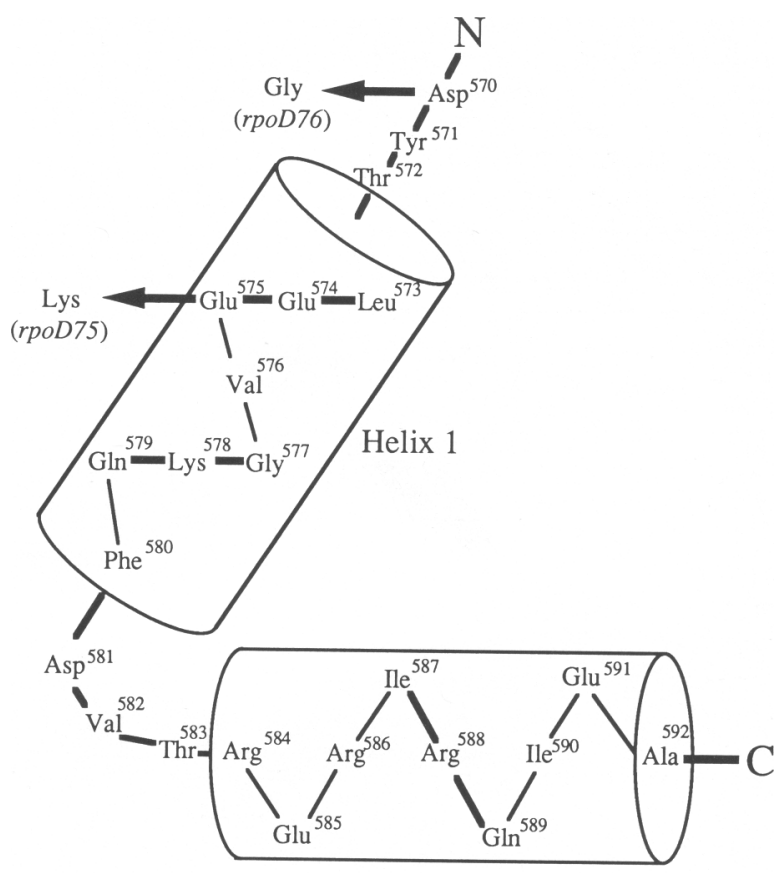

Helix 2

Figure 3. Amino acid substitutions in mutant $\sigma^{70}$ subunits. Schematic diagram of the putative HTH structure of the $\sigma^{70}$ subunit of RNA polymerase is based on Helmann and Chamberlin (1988). The positions of the amino acid substitutions in mutant $\sigma^{70}$ subunits are indicated by arrows. (N and C) Aminoand carboxy-terminal regions of the $\sigma^{70}$ subunit, respectively. 
found in the mutant alleles and because both alterations were included in the $0.6-\mathrm{kb} \mathrm{BamHI}$ fragment, we concluded that these amino acid alterations in $\sigma^{70}$ were responsible for the reduced expression of $p h o A$.

rpoD75 and rpoD76 alleles specifically reduce transcription of the pho regulon

We wanted to know whether the rpoD mutants were defective in a specific interaction with $\mathrm{PhoB}$ and, consequently, specifically defective in transcription of the pho genes. Because the doubling times of these mutants cells in M9 media containing glucose or glycerol were the same as that of their parent strain (ANCD80), these rpoD mutations should not cause general defects in transcription.

To study the effects of the rpoD mutations on transcription of the pho promoters and the other $\sigma^{70}$-dependent promoters, we constructed plasmids that contain the promoters fused to a reporter gene, cat (Table 2) and assayed the activity of these promoters by measuring the levels of chloramphenicol acetyltransferase (CAT) in the wild-type and mutant strains carrying these plasmids (Fig. 4). The -10 and -35 sequences of the tac promoter and the -35 sequences of the trp promoter conform perfectly to the consensus for $\sigma^{70}$ targets (see Fig. 1). The mel promoter used here is a synthetic promoter that contains the cAMP receptor protein (CRP) protein-binding site centered at -41.5 from the transcription initiation site (Bell et al. 1990). The lac promoter contains the CRPbinding site, which is centered at -61.5 from the transcription initiation site and is separated from the -10 and -35 regions. However, none of these promoters con- tain the pho box. The rpoD75 mutation had no effect on transcription initiated from the tac, mel, or lac promoter, whereas it slightly reduced transcription initiated from the trp promoter. The $r p o D 76$ mutation had no effect on the tac and mel promoters, whereas it slightly reduced the activity of the trp and lac promoters. In contrast, the $r p o D$ mutations dramatically reduced the promoter activity of the pho promoters such as the $p h o E$, pstS, phoA, ugpB, and phoK (Fig. 4, bottom). The effect of the rpoD75 mutation was especially impressive: Little or no expression of any pho gene was observed in the rpoD75 mutant just as in the phoB deletion mutant. These particular $r p o D$ mutations specifically inactivated expression of the pho genes without significantly affecting expression of the other $\sigma^{70}$-dependent genes. Therefore, these results are consistent with the hypothesis that $\sigma^{70}$ is the subunit of RNA polymerase that directly interacts with $\mathrm{PhoB}$ protein for transcriptional activation of the pho genes, and the region containing the altered amino acids in the mutant $\sigma^{70}$ subunits is involved in specific contact with PhoB.

\section{Properties of reconstituted RNA polymerases containing RpoD75 or RpoD76}

The wild-type and mutant $\sigma^{70}$ subunits were overproduced by using the cloned genes and the $\mathrm{T} 7$ phage promoter system and purified to near homogeneity (Fig. 5, lanes 2-4) by the method described by Igarashi and Ishihama (1990). The core enzyme was purified from RNA polymerase holoenzyme (Pharmacia) according to the method of Lowe et al. (1979) (Fig. 5, lane 5).

The holoenzymes were reconstituted from the wild-

Table 2. Plasmids used in this study

\begin{tabular}{|c|c|c|}
\hline Plasmid & Properties & Source or reference \\
\hline pRW38 & $r p o D^{+}$gene in pUC18 & this report \\
\hline pRW32 & pRW38 derivative $\left(r p o D^{-}\right)$ & this report \\
\hline pRP80 & $r p o D^{+}$gene in pUCl8 & this report \\
\hline pRP75 & rpoD75 gene in pUC18 & this report \\
\hline pRP76 & rpoD76 gene in pUC18 & this report \\
\hline pT7-5 & T7 promoter plasmid & $\begin{array}{l}\text { S. Tabor (Harvard Medical } \\
\text { School, Boston, MA) }\end{array}$ \\
\hline pTR80 & $r p o D^{+}$gene in pT7-5 & this report \\
\hline pTR75 & rpoD75 gene in pT7-5 & this report \\
\hline pTR76 & rpoD76 gene in pT7-5 & this report \\
\hline pKK232-8 & CAT assay vector & Pharmacia \\
\hline pKT299 & tac promoter in pKK232-8 & this report \\
\hline pKM66 & melR promoter in $\mathrm{pKK} 232-8$ & this report \\
\hline pKT94 & $\operatorname{trp}$ promoter in $\mathrm{pKK} 232-8$ & this report \\
\hline pKL229 & lac promoter in $\mathrm{pKK} 232-8$ & this report \\
\hline pUT94 & trp promoter in pUC19 & this report \\
\hline pOS 1 & pstS promoter in $\mathrm{pLKK} 232-8$ & Kimura et al. (1989) \\
\hline pKA064 & phoA promoter in $\mathrm{pKK} 232-8$ & Yamada et al. (1989) \\
\hline pKE205 & phoE promoter in pKK $232-8$ & Yamada et al. (1989) \\
\hline pKD513 & ugp $B$ promoter in $\mathrm{pKK} 232-8$ & Kasahara et al. (1991) \\
\hline pKC94 & phoK promoter in $\mathrm{pKK} 232-8$ & $\begin{array}{l}\text { S.-K. Kim, K. Makino, M. Amemura, } \\
\text { H. Shinagawa, and A. Nakata, (in prep.) }\end{array}$ \\
\hline pSD506 & pst $S$ promoter in $\mathrm{pKK} 232-8$ & Kimura et al. (1989) \\
\hline
\end{tabular}




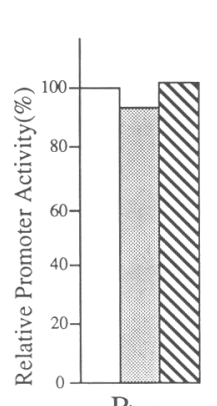

Ptac

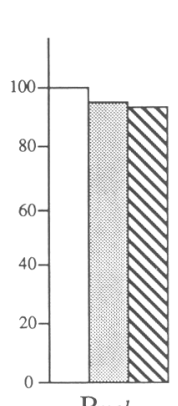

Pmel

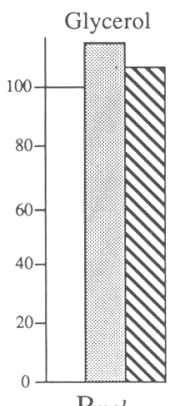

Pmel

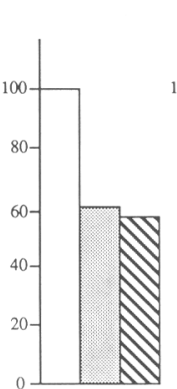

Ptrp

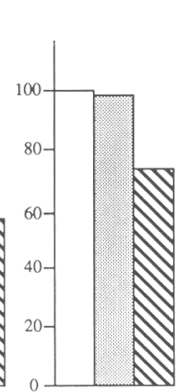

Plac
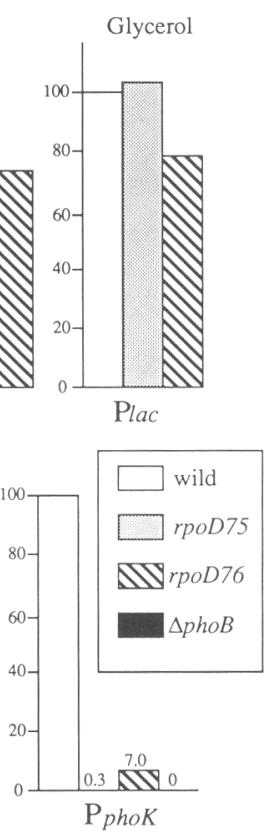

Glycerol

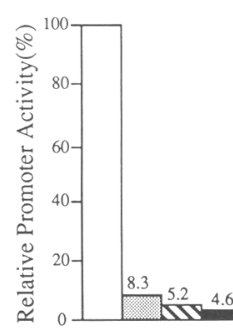

$\mathrm{P}_{\text {phoE }}$
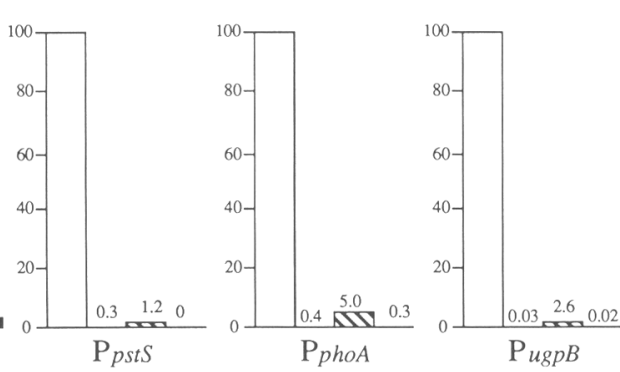

\section{descr} one-hundredth volume of the overnight
cultures grown in T-broth was inoculated into fresh M9 glucose or glycerol medium. After $10 \mathrm{hr}$ of incubation at $37^{\circ} \mathrm{C}$, the CAT activitics of the cells were measured as described in Materials and method. The bar graphs represent relative CAT activities of the mutants carrying the plasmids with the promoter fusions as compared with those of the wild-type strain (ANCC2) carrying the same plasmids. The data are the averages of three experiments. Isogenic strains ANCC2 (wild), ANCD75 (rpoD75), ANCD76 (rpoD76), and ANCD801 $(\triangle p h o B)$ used as hosts for each plasmid are marked as shown in the inset. (Top) Activities of PhoB-independent promoters (Ptac, Pmel, Ptrp, and Plac). M9 glycerol medium (labeled) was used instead of M9 glucose medium for assay of catabolite-sensitive promoters (Pmel and Plac). For tac and lac promoter assays, cells were grown in the presence of $1 \mathrm{~mm}$ isopropyl $\beta$-D-thio-galactopyranoside (IPTG) to inactivate the LacI repressor. For the trp promoter assay, cells were grown in the presence of $1 \mathrm{~mm} 3 \beta$-indoleacrylic acid (IAA) to inactivate the TrpR repressor. (Bottom) Promoter activities of PhoB-dependent promoters (PphoE, PpstS, PphoA, PugpB, and PphoK). CAT activities of the parental strain ANCC2 containing pKT299 (Ptac), pKM66 (Pmel), pKM66 with glycerol, pKT94 (Ptrp), pKL229 (Plac), pKL229 with glycerol, pKE205 (PphoE), pOS1 (PpstS), pKA064 (PphoA), pKD513 (PugpB), and pKC94 (PphoK) were 626, 34, 120, 114, 54, 349, 52, 114, 117, 165, and 239 units, respectively. The CAT activity of ANCC2 containing the CAT vector pKK232-8 was $<0.01$ units.

type core enzyme and $\mathrm{RpoD}^{+}, \mathrm{RpoD75}$, or RpoD76, whose activity was assayed by in vitro single-round transcription using mixed linear DNA templates carrying

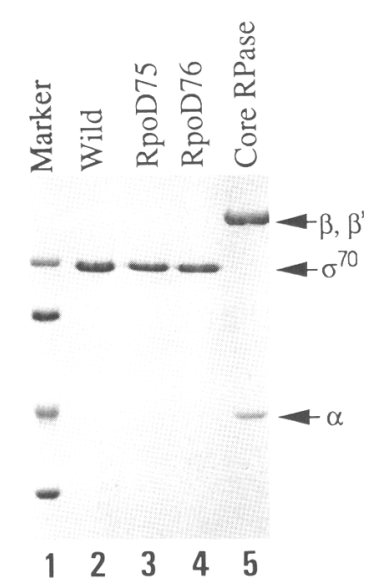

Figure 5. SDS-PAGE of purified wild-type and mutant $\sigma^{70}$ subunits and RNA polymerase core enzyme. The $\sigma^{70}$ subunits of $\mathrm{RpoD}^{+}$(wild), RpoD75, and RpoD76 (lanes 2-4) and the RNA polymerase core enzyme (lane 5 ) were purified as described in Materials and methods. Samples (10 pmoles of each) were electrophoresed on a $10 \%$ SDS-polyacrylamide gel. The gel was stained with Coomassie brilliant blue. (Lane 1) Marker proteins: $94,67,43$, and $30 \mathrm{kD}$ from the top. the tac and trp promoters (Fig. 6). As shown previously (Igarashi and Ishihama 1990), in addition to the core enzyme, $\sigma^{70}$ was required for specific transcription initiated from the tac and trp promoters. The products transcribed from the tac template using the holoenzymes containing RpoD75 or RpoD76 were indistinguishable from that using the wild-type holoenzyme, indicating that RpoD75 and RpoD76 did not alter the specific interaction of $\sigma^{70}$ with the tac promoter. The mutant holoenzymes were only slightly less efficient in transcribing the trp promoter than the wild-type enzyme.

We then studied the ability of the holoenzyme containing the mutant RpoD proteins to transcribe the pstS promoter as a representative pho promoter. As shown previously (Makino et al. 1989), transcription of pstS requires phosphorylated $\mathrm{PhoB}$ in addition to RNA polymerase holoenzyme containing $\sigma^{70}$, whereas transcription of tac does not require PhoB (Fig. 7). The mutant RNA polymerases were severely defective in transcribing pstS even in the presence of phosphorylated PhoB: No pstS transcript was detected with the enzyme containing RpoD75, and only $\sim 5 \%$ pst $S$ transcript was made with the enzyme containing RpoD76 as compared with the wild-type enzyme. The tac DNA template, which was included in the same reaction as an internal control, was transcribed with the same efficiency by the wildtype and mutant enzymes either in the presence or absence of phosphorylated PhoB. Therefore, RpoD75 and 


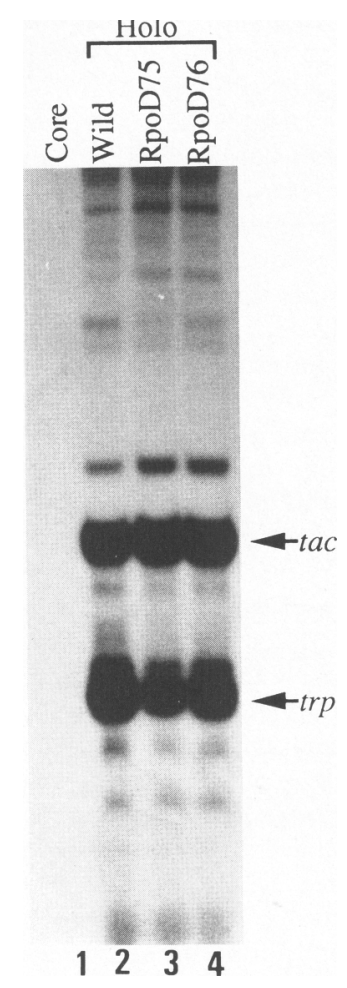

Figure 6. Promoter-dependent transcription by reconstituted wild-type and mutant RNA polymerases. Single-round in vitro transcription was carried out with DNA templates containing the tac (0.05 pmole) and trp (0.1 pmole) promoters. For each reaction, 1.5 pmole of RNA polymerase core enzyme was used. To reconstitute the RNA polymerase holoenzyme, the core RNA polymerase was preincubated with fourfold molar excess of the $\sigma^{70}$ subuint (6 pmoles) of $\mathrm{RpoD}^{+}$(wild), RpoD75, or RpoD76 (lanes 2-4). Specific transcripts are indicated by arrows.

RpoD76 were not defective in the formation of the active RNA polymerase holoenzyme with the core enzyme for the transcription of genes that do not require the activator protein $\mathrm{PhoB}$, but they were defective in specific interaction with the PhoB-dependent promoter pstS. In vitro results are consistent with in vivo results that the mutants are specifically defective in transcription of the pho genes (Fig. 4).

\section{RNA polymerases containing RpoD75 or RpoD76 are defective in PhoB-mediated binding to the pstS promoter}

We wanted to determine whether PhoB promotes binding of RNA polymerase to the pho promoters by interacting with $\sigma^{70}$. Binding of RNA polymerase and PhoB to the promoter region of $p s t S$ was analyzed by the ability of these proteins to protect DNA from DNase I digestion (Fig. 8). No binding of RNA polymerase to the pstS promoter region was detected in the absence of phosphorylated PhoB (lanes 3-5). As reported previously (Makino et al. 1989), phosphorylated $\mathrm{PhoB}$ protected from digestion the pstS promoter region covering -16 to -64 , which contains two sets of pho boxes (lane 6). RNA polymerase containing the wild-type $\sigma^{70}$ subunit bound to the pstS promoter region in the presence of phosphorylated $\mathrm{PhoB}$, as a more extended region of $p s t S(+20$ to -64$)$ was protected by the combination of these proteins than by phosphorylated PhoB alone (lanes 6,7). It should be noted that footprinting detects formation of stable complexes, which are usually open complexes. However RNA polymerases containing RpoD75 or RpoD76 were defective in binding to the promoter, more so with RpoD75 than RpoD76, as they protected the promoter region much less efficiently than the wild-type RNA polymerase $($ lanes 8,9$)$. These results are consistent with our hypothesis that phosphorylated PhoB bound to the pho box promotes the entry of RNA polymerase into the pho promoters by binding to the $\sigma^{70}$ subunit in the holoenzyme complex. The amino acids altered in these mutant $\sigma^{70}$ subunits could play important roles in a specific interaction with PhoB.

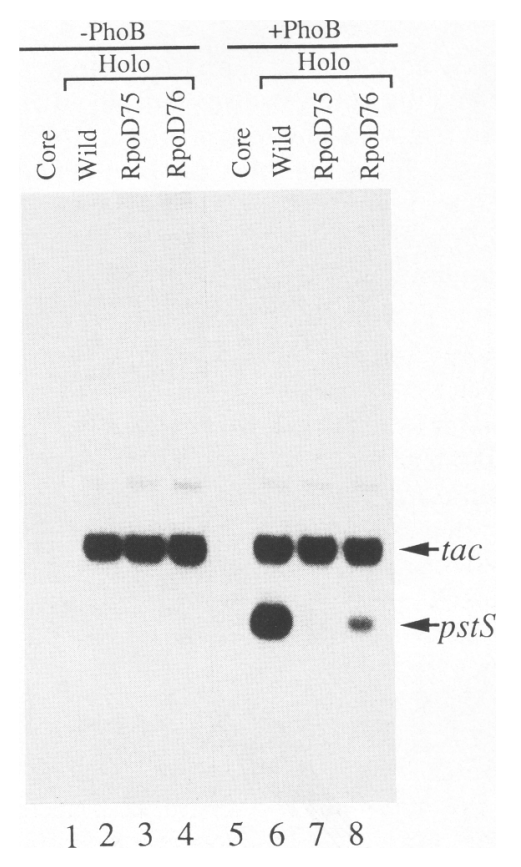

Figure 7. In vitro transcription of the PhoB-dependent pstS promoter by reconstituted wild-type and mutant RNA polymerases. Single-round in vitro transcription was carried out using tac $(0.05$ pmole) and pstS (0.05 pmole) promoters. For each reaction, 1 pmole of RNA polymerase core enzyme was used. The holoenzymes were reconstituted by incubating the core RNA polymerase with the $\sigma^{70}$ subunit of $\mathrm{RpoD}^{+}$(wild), RpoD75, or RpoD76. For the PhoB-dependent transcription, PhoB was phosphorylated by PhoR 1084 before the addition of RNA polymerase as described in Materials and methods. (Lanes 1,5) Core RNA polymerase; (lanes 2,6) reconstituted wild-type RNA polymerase holoenzyme; (lanes 3,7 ) reconstituted holoenzyme containing RpoD75; (lanes 4,8) reconstituted holoenzyme containing RpoD76. Reaction mixtures analyzed in lanes 5-8 contained PhoB (4 pmoles) phosphorylated by the PhoR1084 protein ( 4 pmoles) in addition to RNA polymerases. Specific transcripts are indicated by arrows. 


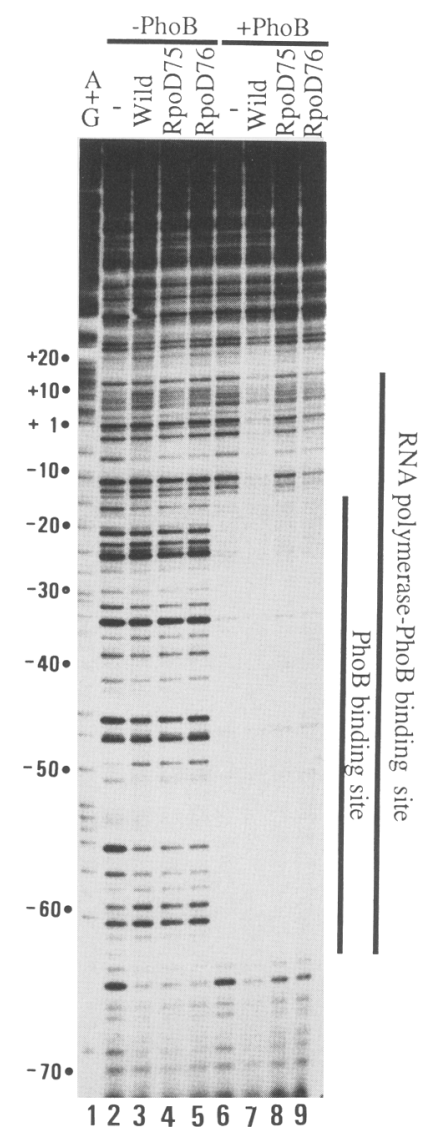

Figure 8. Footprints of the reconstituted RNA polymerases and phosphorylated $\mathrm{PhoB}$ on the pstS promoter. Protection of the pstS promoter from DNase I digestion by the RNA polymerase holoenzymes containing either wild-type or mutant $\sigma^{70}$ and phosphorylated PhoB was examined as described in Materials and Methods. (Lanes 2,6) No RNA polymerase; (lanes 3,7) reconstituted wild-type RNA polymerase holoenzyme; (lanes 4,8) reconstituted RNA polymerase containing RpoD75; (lanes 5,9) reconstituted RNA polymerase containing RpoD76. In the reaction mixtures analyzed in lanes $6-9$ PhoB (4 pmoles) phosphorylated by PhoR1084 (4 pmoles) was included, as shown at the top. Lane 1 indicates the Maxam-Gilbert A+G reaction of the pstS promoter DNA. Numbers at left indicate the distance in bases from the start point of $p s t S$ mRNA (Makino et al. 1988). Areas protected from DNase I digestion are indicated at right.

\section{Discussion}

The pho promoters share the conserved -10 sequence of $\sigma^{70}$ and the 18-bp sequence called the pho box, located 10 bp upstream of the -10 sequence (Fig. 1; Makino et al. 1986, 1991; Kasahara et al. 1991). The importance of the -10 sequence for the pho promoter activity has been demonstrated for the pstS promoter (Kimura et al. 1989). In vitro transcription of the pho genes requires the RNA polymerase containing $\sigma^{70}$ in addition to phosphorylated PhoB (Makino et al. 1988, 1989), which also suggests the functional importance of the -10 sequence for the pho promoters. PhoB, the activator of the pho genes, binds to the pho box with high affinity upon phosphorylation and activates the transcription from the pho promoters. In the absence of functional $\mathrm{PhoB}$, no transcription of the pho genes is detected either in vivo or in vitro (Shinagawa et al. 1987; Makino et al. 1989|. The RNA polymerase containing $\sigma^{70}$ cannot bind to the pho promoter in the absence of phosphorylated PhoB (Fig. 8), which suggests that the -35 regions of the pho promoters cannot function as the recognition sequences for $\sigma^{70}$. The fact that the RNA polymerase can bind to the pho promoter only in the presence of phosphorylated PhoB shows that PhoB bound to the pho box mediates the binding of the RNA polymerase to the pho promoter, which lacks the functional -35 sequence for $\sigma^{70}$ interaction. Because transcription of all the pho genes examined here was specifically and severely reduced in the rpoD75 and rpoD76 mutants while the expression of all the other PhoB-independent genes examined was not significantly affected, we postulate that phosphorylated PhoB bound to the pho box makes direct contact with $\sigma^{70}$, and this mediates the specific interaction of the RNA polymerase with the pho promoters to activate transcription as shown in Figure 9. Because RpoD75 and RpoD76 were severely defective in promoting transcription of the pho genes both in vivo and in vitro, $\sigma^{70}$ may be making contact with $\mathrm{PhoB}$ in the region called subregion 4.2 (Helmann and Chamberlin 1988), which contains altered amino acids in these mutant $\sigma^{70}$ subunits. Because the rpoD75 mutant was as defective as the $p h o B$ deletion mutant in promoting the transcription of the pho genes, the altered Glu- 575 at the carboxyl terminus in the rpoD75 mutant may be involved in direct specific contact with PhoB. Glu- 575 has been suggested to be included in the first helix of the HTH motif of $\sigma^{70}$, and Asp-570, which is altered in the rpoD76 mutant, is very close to the putative HTH motif (Helmann and Chamberlin 1988) (Fig. 3). Amino acids in the second putative helix have been implicated in a direct interaction with the specific nucleotides in the -35 region (Gardella et al. 1989; Siegele et al. 1989), whereas the first helix has been suggested to facilitate the interaction indirectly (Helmann and Chamberlin 1988). However, the pho promoters lack the consensus -35 sequence and, therefore, lack the target sequences for the interaction of subregion 4.2 . The contact region of $\sigma^{70}$ with the -10 sequence has been assigned to the middle of the peptide called subregion 2.4 (Helmann and Chamberlin 1988; Siegele et al. 1989; Waldburger et al. 1990). The proposed PhoB interaction with $\sigma^{70}$ may compensate for the absence of the normal interaction between $\sigma^{70}$ and consensus -35 sequence by substituting for that interaction (Fig. 9). Consistent with this hypothesis, the exact 10-bp spacing between the pho box and the -10 sequence is observed in all of the pho promoters (see Fig. 1). This special restriction may be defined by the specific interaction of a particular domain of PhoB with the first helix of the HTH motif in subregion 4.2 of $\sigma^{70}$.

The rpoD75 and rpoD76 mutations have been independently isolated and characterized by Siegele et al. (1988) as the mutations that moderately increased the low level of transcription from the lac promoter in a cya 
Figure 9. Schematic presentation of transcriptional activation by RNA polymerase at three kinds of promoters. The -10 and -35 signals, PhoB-binding sites (pho box), and CRP-binding sites in the three types of promoters are shown. The subunits of RNA polymerase, CRP, and PhoB are illustrated as indicated. (A) Activator-independent promoters: empty $(a)$ or bound by RNA polymerase $(b)$. The $\sigma^{70}$ subunit mediates interaction between RNA polymerase and the promoter by making direct contact with the -10 and -35 sites. $(B)$ PhoB-dependent promoters: empty $(a)$, bound by PhoB $(b)$, or bound by PhoB and RNA polymerase (c). PhoB bound to the pho box promotes interaction of RNA polymerase with the promoter via direct contact with the $\sigma^{70}$ subunit. Although $\sigma^{70}$ interaction with the -10 site of the pho promoter is required, it alone is not enough for the formation of stable complex with the promoter. The process requires the function of $\mathrm{PhoB}$ bound to the pho box. (C) CRP-dependent promoters that contain the CRP-binding sites located upstream from the -35 sites: empty $(a)$, bound by CRP $(b)$, or bound by CRP and RNA polymerase (c). CRP bound to the binding site facilitates the interaction of RNA polymerase with the promoter via direct contact with the carboxy-terminal part of the $\alpha$ subunit. Although $\sigma^{70}$ subunit interactions with the -10 and -35 sites are required, they are not enough for the formation of the stable complex with the promoter. Interaction between CRP and RNA polymerase via the $\alpha$ subunit mutually increases their interactions with the promoter.
A

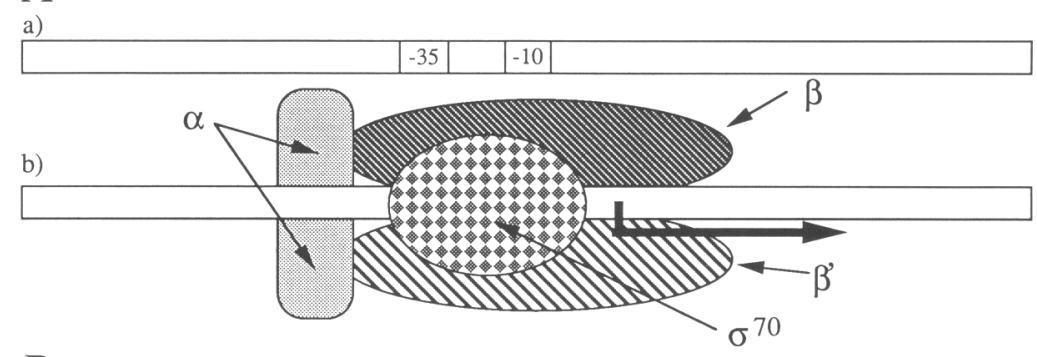

B
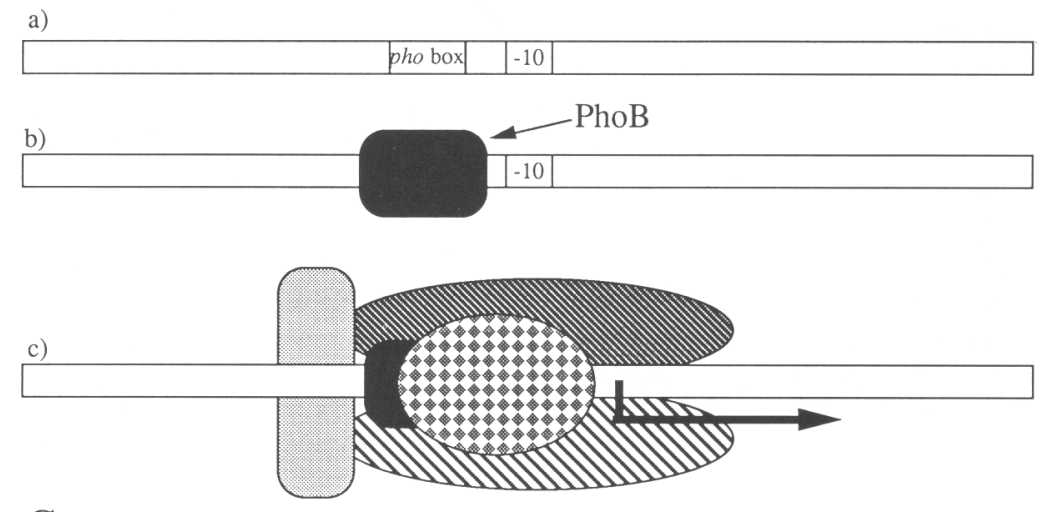

C
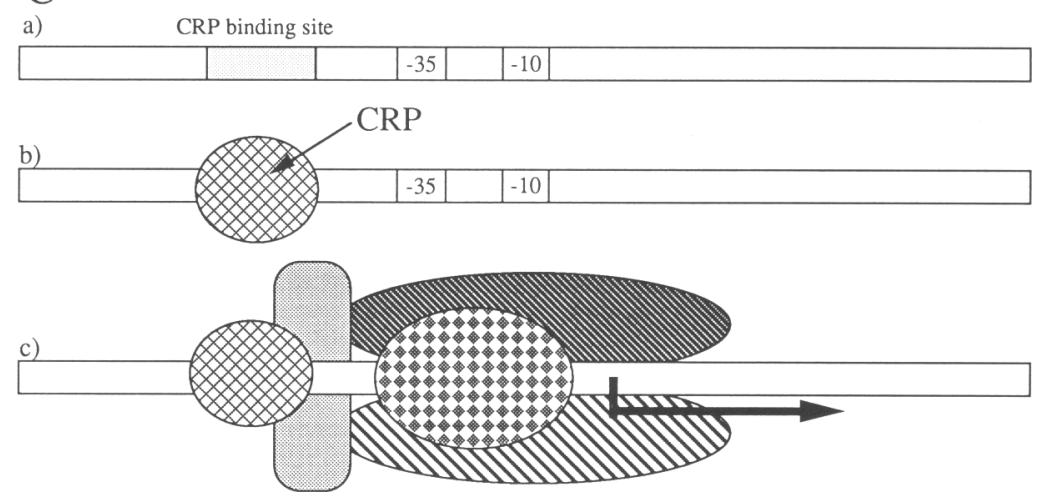

deletion mutant. However, these mutations showed little effect on the transcription levels of $1 a c Z$ gene in the $\mathrm{cya}^{+}$strain (Fig. 4; Siegele et al. 1988). We observed that lacZ expression in a cya- strain was elevated five- or twofold by the introduction of the rpoD75 or rpoD76 mutation, respectively (data not shown). Siegele et al. (1989) studied the effect of the rpoD75 mutation (EK575) on a series of mutant promoters of the lac operon and the ant gene of phage P22. On the basis of their findings that the rpoD75 mutation increased transcription from some of these mutant promoters, which had changes in both the -35 and -10 regions, they proposed that the altered amino acid in the mutant might change sequence-independent interactions with the DNA or protein-protein interactions during initiation, rather than affecting basespecific contacts. It has been suggested that the first helix of the HTH is not involved in direct contact with DNA and modulates the second helix to interact with the -35 sequences of the promoters (Helmann and
Chamberlin 1988). The fact that the rpoD75 and rpoD76 mutations do not significantly affect the expression of the genes that possess the consensus -35 sequence suggests that amino acids altered in these mutants are not involved in direct interactions with the -35 sequence, which was also supported by the experiments of Siegele et al. (1989).

OmpR protein is similar to $\mathrm{PhoB}$ in that it requires phosphorylation by a protein kinase to activate transcription of the genes encoding porins (for review, see Stock et al. 1989). Despite the structural and functional similarities with $\mathrm{PhoB}, \mathrm{OmpR}$ appears to interact with a different subunit of RNA polymerase - $\alpha$ subunit encoded by rpoA-which was supported by suppressor mutant studies (Matsuyama and Mizushima 1987; Slauch et al. 1991). In vitro studies using reconstituted RNA polymerases containing truncated $\alpha$ subunits have demonstrated that the carboxy-terminal portion of the $\alpha$ subunit is required for the transcription of the OmpR-de- 
pendent promoter, but it is dispensable for the PhoBdependent promoter (Igarashi et al. 1991). These data are consistent with the hypothesis drawn from the present work that $\mathrm{PhoB}$ mediates interaction between RNA polymerase and the pho promoters by making direct contact with the $\sigma^{70}$ subunit. On the basis of the properties of the rpoD mutations at Arg-596, which increased transcription from the araBCD promoter in the absence of CRP-cAMP under the ar $\mathrm{C}^{+}$background only, Siegele et al. (1989) mentioned that $\sigma^{70}$ might interact with an activator, AraC.

The $\alpha$-subunit of RNA polymerase has been implicated almost exclusively as the subunit involved in direct contacts with some transcriptional activators. A number of rpoA mutants, which are specifically defective in the expression of certain genes whose expression depends on particular activators, such as Fnr (Lombardo et al. 1991), CysB, MetR, and AraC (Rowland et al. 1985; Thomas and Glass 1991), Ogr of phage P2 (Sunshine and Sauer 1975; Fujiki et al. 1976), and the product of the $\delta$ gene of phage P4 (Dale et al. 1986; Halling et al. 1990), have been isolated. Although the mutation sites in all of these mutants have been located in the carboxy-terminal coding region of the $\alpha$ subunit, each mutant usually affects a particular class of promoters, indicating that these activators make unique interactions with the $\alpha$ subunit through slightly different subregions in the carboxy-terminal region. The RNA polymerases containing carboxy-terminally truncated $\alpha$ subunits are unable to support transcription from the CRP-dependent lac and $u x u A B$ promoters (Igarashi and Ishihama 1990) (Fig. 9), but they can support transcription from the CRP-dependent galP1 and PBR-P4 promoters, and the PhoB-dependent $p s t S$ promoter (Igarashi et al. 1991). It should be noted that the promoters that are affected by RNA polymerases with the carboxy-terminally truncated $\alpha$ subunits contain the activator binding sites separated from the -10 and -35 signals, and the promoters that are transcribed by mutant RNA polymerases contain the activator binding sites overlapping the -35 region (Igarashi et al. 1991). From these observations, we suspect that activators interacting with the sites overlapping the -35 region or located farther downstream might interact with $\sigma^{70}$. In the case of CRP-cAMP, two modes of activation, depending on the location of the binding site, were also proposed by Gaston et al. (1990). Bell et al. (1990) isolated a mutant CRP that can activate transcription from a promoter with the CRP site centered at -41.5 but not from a promoter with the CRP site centered at -61.5 , suggesting that CRP can use different contacts and/or conformations for transcriptional activation between these two types of promoters. We wanted to determine whether the synthetic mel promoter that contains the CRP-binding site centered at -41.5 (overlapping the -35 region) (see Fig. 1) interacts with the same region of $\sigma^{70}$ as the pho promoters. The mel promoter was as activated in the rpoD75 and rpoD76 mutants as in the wild-type strain (Fig. 4), but this does not exclude the possibility that CRP bound at the -41.5 site interacts with $\sigma^{70}$ at slightly different regions of the $\sigma^{70}$ subunit.

In this work we have demonstrated that PhoB promotes binding of RNA polymerase to the pho promoters; and on the basis of rpoD mutant analysis, we propose that PhoB makes direct contact with $\sigma^{70}$ at the subregion that includes Glu-575 and Asp-570. However, it also remains possible that PhoB contacts a different part of RNA polymerase or that $\mathrm{PhoB}$ affects DNA conformation in the promoter region upon binding in a manner that promotes the interaction between the $\sigma^{70}$ subunit of RNA polymerase and the pho promoters, or both. In any case, the $\sigma^{70}$-subunit appears to play an essential role in the interactions between PhoB protein and RNA polymerase on the pho promoters. Our hypothesis predicts that a $p h o B$ mutant might be obtained that suppresses the rpoD75 mutation by recovering the interaction between PhoB and RpoD75. In fact, such a mutant has been isolated by localized mutagenesis of the $p h o B$ gene, and the mutation has been mapped to the carboxy-terminal coding region. However, the mutation suppressed both the rpoD75 and rpoD76 mutations and, therefore, is not allele specific (K. Makino, M. Amemura, H. Shinagawa, and A. Nakata, unpubl.). RNA polymerase containing a carboxy-terminally truncated $\sigma^{70}$, which has a deletion up to the second helix of the putative HTH could not transcribe most of promoters, but it could transcribe the pst $S$ promoter in the presence of PhoB protein in vitro (A. Kumar, B. Grimes, N. Fujita, K. Makino, R.A. Malloch, R.S. Hayward, and A. Ishihama unpubl.). These results are consistent with our hypothesis that the altered amino acids near and within the first helix of the HTH motif of the $\sigma^{70}$ subunit make contacts with PhoB bound to the pho promoters. We also predict that there may be other activators like PhoB that interact with $\sigma^{70}$ to activate transcription among those activators that possess their recognition sequences overlapping the -35 region. This work suggests versatile mechanisms of transcriptional activation by activator proteins.

\section{Materials and methods}

\section{Media and strains}

LB, T, and M9 plates and liquid media were made as described by Miller (1972). M9 plates and media were supplemented with glucose $(0.4 \%)$ or glycerol $(0.4 \%)$ and amino acids $(20 \mu \mathrm{g} / \mathrm{ml})$. Ampicillin $(100 \mu \mathrm{g} / \mathrm{ml})$, tetracycline $(20 \mu \mathrm{g} / \mathrm{ml})$, and XP (40 $\mu \mathrm{g} / \mathrm{ml}$ ) were added when required. Transduction using Plvir was done as described by Miller (1972). Strains used in this study are shown in Table 3. Strain ANCD801 $[\Delta(p h o B-p h o R)$ $\left.\mathrm{Km}^{\mathrm{r}}\right]$ was constructed by $\mathrm{Pl}$ transduction from ANCH1 [ $\Delta\left(\right.$ phoB-phoR) $\left.\mathrm{Km}^{\mathrm{r}}\right]$ (Yamada et al. 1989) to ANCD80. ANC strains are isogenic except for the indicated alleles.

\section{Localized mutagenesis of $\mathrm{rpoD}$}

Cultures of CAG12152 (zgh-3075::Tn10) were mutagenized with $N$-methyl- $N^{\prime}$-nitro- $N$-nitrosoguanidine by a standard protocol (Miller 1972) and grown overnight in LB. Plvir lysate grown on the mutagenized cultures was used to transduce the tetracycline resistance marker into ANCC2, and the transduc- 
Table 3. Strains used in this study

\begin{tabular}{|c|c|c|}
\hline Strain & Genotype & $\begin{array}{l}\text { Reference } \\
\text { or origin }\end{array}$ \\
\hline CAG 12152 & $z g h-30575:: \operatorname{Tn} 10$ & $\begin{array}{l}\text { Singer et al. } \\
(1989)\end{array}$ \\
\hline ANCC2 & $\begin{array}{l}\text { leu phoR68 trp his } \\
\text { argG strA ilv met } A \\
\text { (or met } B \text { ) thi }\end{array}$ & $\begin{array}{l}\text { Makino et al. } \\
\text { (1982) }\end{array}$ \\
\hline ANCD80 & $\begin{array}{l}\text { as ANCC2, except for } \\
z g h-3075:: \operatorname{Tn} 10\end{array}$ & $\begin{array}{l}\text { P1 (CAG12152) } \\
\times \text { ANCC } 2\end{array}$ \\
\hline ANCD75 & $\begin{array}{l}\text { as ANCD80, except for } \\
\text { rpoD75 }\end{array}$ & this report \\
\hline ANCD76 & $\begin{array}{l}\text { as ANCD80, except for } \\
\text { rpoD76 }\end{array}$ & this report \\
\hline ANCD801 & $\begin{array}{c}\text { as ANCD80, except for } \\
\Delta(p h o B-p h o R) \mathrm{Km}^{\mathrm{r}}\end{array}$ & this report \\
\hline
\end{tabular}

tants were selected on LB plates containing tetracycline. After incubation at $37^{\circ} \mathrm{C}$ overnight, the plates were replicated onto M9 glucose plates containing tetracycline and XP. On these plates, APase-producing colonies are blue, and nonproducing colonies are white.

\section{Enzyme assays}

Assays of APase and CAT were performed as described previously by Makino et al. (1982) and Kimura et al. (1989), respectively.

\section{Plasmid construction}

Plasmids used in this study are described in Table 2. A set of $\sigma^{70}$ expression plasmids was constructed as follows: The $3.8 \mathrm{-kb}$ $E c 0 \mathrm{O} 109$ fragment containing the $r p o D$ gene was prepared from $\lambda 19 F 2$, one of the ordered clones of the E. coli genomic library constructed by Kohara et al. (1987). After the protruded ends were filled in by Klenow enzyme, the fragment was ligated with pUC18 (Yanisch-Perron et al. 1985), which had been digested with SmaI enzyme. The resultant plasmid was designated pRW38 (Fig. 2). Chromosomal DNAs of ANCD80, ANCD75, and ANCD76 were cut with EcoO109, and the protruding ends were filled in with Klenow enzyme. The $3.8-\mathrm{kb}$ DNA fragments were electroeluted from the agarose gel and ligated with pUCl 8 DNA, which had been linearized with SmaI. The DNAs were transformed into JM103 (Yanisch-Perron et al. 1985), and the transformants containing the $r p o D$ plasmids were selected by colony hybridization. Plasmids containing the $r p o D$ fragments in the same orientation as pRW38 were selected and designated pRP80 (rpoD ${ }^{+}$), pRP75 (rpoD75), and pRP76 (rpoD76) (Fig. 2).

Overproduction of the wild-type and mutant $\sigma^{70}$ subunits was achieved by employing the strong $\mathrm{T} 7$ phage promoter on plasmid pT7-5, and E. coli BL21 ( $\lambda \mathrm{DE} 3$ ) was used as the host strain (Studier and Moffatt 1986). The 2.1-kb SacI-HindIII fragments containing the $r p o D$ region were isolated from pRP80, pRP75, and pRP76 and ligated with pT7-5 digested previously with SacI and HindIII enzymes. The resultant plasmids were designated correspondingly as pTR80, pTR75, and pTR76.

A set of promoters fused to the cat gene was constructed as follows: pKT299 was constructed by ligating the 299-bp BamHI-HindIII fragment of pKK233-2 lobtained from Pharmacia) containing the tac promoter with pKK232-8 digested previously with BamHI and HindIII. pKM66 was constructed by li- gating the synthetic 62-bp DNA fragment, which contains essentially the same features as the melR promoter as described by Bell et al. (1990), with pKK232-8 digested previously with BamHI and HindIII. The sequence of the synthetic DNA is

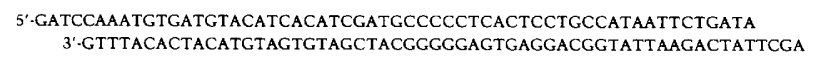

The 94-bp HindIII-BamHI fragment of pDR720 (Pharmacia) containing the $\operatorname{trp}$ promoter was filled in by Klenow enzyme and ligated with pKK232-8 DNA digested previously with SmaI enzyme. The resultant plasmid was designated pKT94. The same fragment, which had not been treated with Klenow enzyme, was ligated with pUC19 (Yanisch-Perron et al. 1985) treated previously with BamHI and HindIII. The plasmid was designated pUT94. pKL229 was constructed by ligating the 229bp PvuII-HindIII fragment of pUC18 carrying the lac promoter with pKK232-8 digested previously with SmaI and HindIII.

\section{Overproduction and purification of proteins}

Overproduction and purification of PhoB and PhoR1084, a truncated form of PhoR protein lacking the amino-terminal hydrophobic region, were described previously (Makino et al. 1988; 1989). Purification of the overexpressed $\sigma^{70}$ subunits was carried out as described by Igarashi and Ishihama (1990). The core RNA polymerase was purified from the RNA polymerase holoenzyme purchased from Pharmacia by the method of Lowe et al. (1979).

\section{Reconstitution of RNA polymerase and in vitro transcription}

To reconstitute holoenzyme, the core enzyme was mixed with fourfold molar excess of each type of the $\sigma^{70}$ subunits in the transcription buffer [ $50 \mathrm{~mm}$ Tris- $\mathrm{HCl}(\mathrm{pH} 7.5), 50 \mathrm{mM} \mathrm{NaCl}, 10$ $\mathrm{mM} \mathrm{MgCl}, 0.1 \mathrm{~mm}$ EDTA, $1 \mathrm{~mm}$ dithiothreitol], and the mixture was incubated for $20 \mathrm{~min}$ at $30^{\circ} \mathrm{C}$.

Single-round in vitro transcription was carried out as described by Makino et al. (1989). In brief, a reaction mixture of template DNA and reconstituted RNA polymerase at indicated concentrations in $35 \mu l$ of the transcription buffer was preincubated for $10 \mathrm{~min}$ at $37^{\circ} \mathrm{C}$ to allow for the formation of open complexes. The substrate solution $(15 \mu l)$ containing heparin (final concentration, $200 \mu \mathrm{g} / \mathrm{ml}$ ) was then added to initiate one round of RNA synthesis. After 5 min, labeled transcripts were precipitated with ethanol and analyzed by electrophoresis on polyacrylamide gels containing $8 \mathrm{M}$ urea. For transcription of the PhoB-dependent pst $S$ promoter, a mixture of the template DNA, PhoB (4 pmoles), PhoR1084 (4 pmoles), and $0.1 \mathrm{~mm} \mathrm{ATP}$ was incubated for $10 \mathrm{~min}$ at $37^{\circ} \mathrm{C}$ to promote phosphorylation of $\mathrm{PhoB}$ and binding of phosphorylated PhoB to the pho box before the addition of RNA polymerase. The following templates were used: the 299-bp BamHI-HindIII fragment of pKK233-2 (Pharmacia) carrying the tac promoter; the 109-bp HindIII-SacI fragment of pUT94 carring the trp promoter; and the 115-bp BamHI-HindIII fragment of pOSl carrying the pstS promoter. The predicted lengths of the run-off transcripts from the tac, trp, and pstS promoters are 56,36, and 41 nucleotides, respectively.

\section{Footprinting experiment}

The $0.9-\mathrm{kb}$ BamHI-PvuII fragment containing the pstS promoter was isolated from pDS506 (Kimura et al. 1989) and labeled at the BamHI site with $\left[\gamma^{-32} \mathrm{P}\right]$ ATP using bacterial alkaline phosphatase and phage $\mathrm{T} 4$ polynucleotide kinase. The reaction mixture $(200 \mu \mathrm{l})$ containing end-labeled DNA $(0.02 \mathrm{pmole})$ and reconstituted RNA poylmerase ( 1 pmole of core enzyme and 4 
pmoles of wild-type or mutant $\left.\sigma^{70}\right)$, with or without PhoR1084 (4 pmoles), PhoB (4 pmoles), and $0.1 \mathrm{~mm}$ ATP in the transcription buffer, was incubated at $37^{\circ} \mathrm{C}$ for $10 \mathrm{~min}$. DNase I ( $15 \mathrm{ng}$ ) was added, and the mixture was incubated for $1 \mathrm{~min}$ at $37^{\circ} \mathrm{C}$. The reaction was stopped by adding $50 \mu \mathrm{l}$ of a solution containing $8 \mathrm{M}$ ammonium acetate and $100 \mu \mathrm{g} / \mathrm{ml}$ of tRNA. DNA was precipitated from the reaction mixtures with ethanol. The reaction products were analyzed by electrophoresis in a polyacrylamide gel containing $8 \mathrm{~m}$ urea.

\section{Acknowledgements}

We thank A. Ishihama (National Institute of Genetics) and $H$. Aiba (Nagoya University) for instructive discussion. We thank Carol A. Gross and M. Singer (University of Wisconsin-Madison) for providing their collection of strains, Y. Kohara (National Institute of Genetics) for providing the $\lambda$-ordered clones of the $E$. coli genome, and S. Tabor (Harvard Medical School) for providing the T7 expression system. This work was supported by a Grant-in-Aid for Scientific Research from the Ministry of Education, Science and Culture of Japan to K.M.

The publication costs of this article were defrayed in part by payment of page charges. This article must therefore be hereby marked "advertisement" in accordance with 18 USC section 1734 solely to indicate this fact.

\section{References}

Bell, A., K. Gaston, R. Williams, K. Chapman, A. Kolb, H. Buc, S. Minchin, J. Williams, and S. Busby. 1990. Mutations that alter the ability of the Escherichia coli cyclic AMP receptor protein to activate transcription. Nucleic Acids Res. 18: $7243-7250$.

Dale, E.C., G.E. Christie, and R. Calendar. 1986. Organization and expression of the satellite bacteriophage P4 late gene cluster. J. Mol. Biol. 192: 793-803.

de Crombrugghe, B., S. Busby, and H. Buc. 1984. Cyclic AMP receptor protein: Role in transcription activation. Science 224: 831-838.

Fujiki, H., P. Palm, W. Zilling, R. Calendar, and M. Sunshine. 1976. Identification of a mutant within the structural gene for the $\alpha$ subunit of DNA-dependent RNA polymerase of $E$. coli. Mol. \& Gen. Genet. 145: 19-22.

Gardella, T., H. Moyle, and M.M Susskind. 1989. A mutant Escherichia coli $\sigma^{70}$ subunit of RNA polymerase with altered promoter specificity. I. Mol. Biol. 206: 579-590.

Garrett, S. and T.J. Silhavy. 1987. Isolation of mutations in the $\alpha$ operon of Escherichia coli that suppress the transcriptional defect conferred by a mutation in the porin regulatory gene envZ. J. Bacteriol. 169: 1379-1385.

Gaston, K., A. Bell, A. Kolb, H. Buc, and S. Busby. 1990. Stringent spacing requirements for transcription activation by CRP. Cell 62: 733-743.

Halling, C., M.G. Sunshine, K.B. Lane, E.W. Six, and R. Calendar. 1990. A mutation of the transactivation gene of satellite bacteriophage P4 that suppresses the rpoA109 mutation of Escherichia coli. J. Bacteriol. 172: 3541-3548.

Helmann, J.D. and M.J. Chamberlin. 1988. Structure and function of bacterial sigma factors. Annu. Rev. Biochem. 57: 839-872.

Igarashi, K. and A. Ishihama. 1990. Bipartite functional map of the $E$. coli RNA polymerase $\alpha$ subunit: Involvement of the $\mathrm{C}$-terminal region in transcription activation by CAMP-CRP. Cell 65: 1015-1022.

Igarashi, K., A. Hanamura, K. Makino, H. Aiba, H. Aiba, T. Mizuno, A. Nakata, and A. Ishihama. 1991. Functional map of the $\alpha$ subunit of Escherichia coli RNA polymerase: Two modes of transcription activation by positive factors. Proc. Nat1. Acad. Sci. 88: 8958-8962.

Kasahara, M., K. Makino, M. Amemura, A. Nakata, and H. Shinagawa. 1991. Dual regulation of the ugp operon by phosphate and carbon starvation at two interspaced promoters. $J$. Bacteriol. 173: 549-558.

Kimura, S., K. Makino, H. Shinagawa, M. Amemura, and A. Nakata. 1989. Regulation of the phosphate regulon of Escherichia coli: Characterization of the promoter of the pstS gene. Mol. \& Gen. Genet. 215: 374-380.

Kohara, Y., K. Akiyama, and K. Isono. 1987. The physical map of the whole $E$. coli chromosome: Application of a new strategy for rapid analysis and sorting of a large genomic library. Cell 50: 459-508.

Lombardo, M.-J., D. Bagga, and C.G. Miller. 1991. Mutations in rpoA affect expression of anaerobically regulated genes in Salmonella typhimurium. J. Bacteriol. 173: 7511-7518.

Lowe, P.A., D.A. Hager, and R.R. Burgess. 1979. Purification and properties of the $\sigma$ subunit of Escherichia coli DNA-dependent RNA polymerase. Biochemistry 18: 1344-1352.

Makino, K., H. Shinagawa, and A. Nakata. 1982. Cloning and characterization of the alkaline phosphatase positive regulator gene (phoB) of Escherichia coli. Mol. \& Gen. Genet. 187: 181-186.

Makino, K., H. Shinagawa, M. Amemura, and A. Nakata. 1986. Nucleotide sequence of the phoB gene, the positive regulatory gene for the phosphate regulon of Escherichia coli. $J$. Mol. Biol. 190: 37-44.

Makino, K., H. Shinagawa, M. Amemura, S. Kimura, A. Nakata, and A. Ishihama. 1988. Regulation of the phosphate regulon of Escherichia coli: Activation of pstS transcription by PhoB protein in vitro. J. Mol. Biol. 203: 85-95.

Makino, K., H. Shinagawa, M. Amemura, T. Kawamoto, M. Yamada, and A. Nakata. 1989. Signal transduction in the phosphate regulon of Escherichia coli involves phosphotransfer between PhoR and PhoB proteins. I. Mol. Biol. 210: $551-559$.

Makino, K., S.-K. Kim, H. Shinagawa, M. Amemura, and A. Nakata. 1991. Molecular analysis of the cryptic and functional phn operons for phosphonate use in Escherichia coli K-12. J. Bacteriol. 173: 2665-2672.

Matsuyama, S. and S. Mizushima. 1987. Novel rpoA mutation that interferes with the function of OmpR and EnvZ, positive regulators of the ompF and ompC genes that code for outer-membrane proteins in Escherichia coli K12. J. Mol. Biol. 195: 847-853.

Miller, J.H. 1972. Experiments in molecular genetics. Cold Spring Harbor Laboratory, Cold Spring Harbor, New York.

Nakata, A., M. Amemura, K. Makino, and H. Shinagawa. 1987. Genetic and biochemical analysis of the phosphate-specific transport system in Escherichia coli. In Phosphate metabolism and cellular regulation in microorganisms (ed. A. Torriani-Gorini, F.G. Rothman, S. Silver, A. Wright, and E. Yagil), pp. 150-155. American Society for Microbiology, Washington, D.C.

Rowland, G.C., P.M. Giffard, and I.R. Booth. 1985. phs locus of Escherichia coli, a mutation causing pleiotropic lesions in metabolism, is an rpoA allele. J. Bacteriol. 164: 972-975.

Shinagawa, H., K. Makino, M. Amemura, and A. Nakata. 1987. Structure and function of the regulatory genes for the phosphate regulon in Escherichia coli. In Phosphate metabolism and cellular regulation in microorganisms led. A. TorrianiGorini, F.G. Rothman, S. Silver, A. Wright, and E. Yagil), pp. 20-25. American Society for Microbiology, Washington, D.C. 
Siegele, D.A., J.C. Hu, and C.A. Gross. 1988. Mutations in rpoD, the gene encoding the $\sigma^{70}$ subunit of Escherichia coli RNA polymerase, that increase expression of the lac operon in the absence of CAP-cAMP. I. Mol. Biol. 203: 29-37.

Siegele, D.A., J.C. Hu, W.A. Walter, and C.A. Gross. 1989. Altered promoter recognition by mutant forms of the $\sigma^{70}$ subunit of Escherichia coli RNA polymerase. I. Mol. Biol. 206: 591-603.

Singer, M., T.A. Baker, G. Schnitzler, S.M. Deischel, M. Goel, W. Dove, K.J. Jaacks, A.D. Grossman, J.W. Erickson, and C.A. Gross. 1989. A collection of strains containing genetically linked alternating antibiotic resistance elements for genetic mapping of Escherichia coli. Microbiol. Rev. 53: 124.

Slauch, J.M., F.D. Russo, and T.J. Silhavy. 1991. Suppressor mutations in $r p o A$ suggest that $O m p R$ controls transcription by direct interaction with the $\alpha$ subunit of RNA polymerase. I. Bacteriol. 173: 7501-7510.

Stock, J.B., A.J. Ninfa, and A.M. Stock. 1989. Protein phosphorylation and regulation of adaptive responses in bacteria. $\mathrm{Mi}$ crobiol. Rev. 53: 450-490.

Studier, F.W. and B.A. Moffatt. 1986. Use of bacteriophage T7 RNA polymerase to direct selective high-level expression of cloned genes. J. Mol. Biol. 189: 113-130.

Sunshine, M.G. and B. Sauer. 1975. A bacterial mutation blocking $\mathrm{P} 2$ phage late gene expression. Proc. Natl. Acad. Sci. 72: $2770-2774$.

Thomas, M.S. and R.E. Glass. 1991. Escherichia coli rpoA mutation which impairs transcription of positively regulated systems. Mol. Microbiol. 5: 2719-2725.

Waldburger, C., T. Gardella, R. Wong, and M.M. Susskind. 1990. Changes in conserved region of Escherichia coli $\sigma^{70}$ affecting promoter recognition. J. Mol. Biol. 215: 267-276.

Yamada, M., K. Makino, M. Amemura, H. Shinagawa, and A. Nakata. 1989. Regulation of the phosphate regulon of Escherichia coli: Analysis of mutant $p h o B$ and phoR genes causing different phenotypes. J. Bactriol. 171: 5601-5606.

Yanisch-Perron, C., J. Vieira, and J. Messing. 1985. Improved M13 phage cloning vectors and host strains: Nucleotide sequences of the M13mpl8 and pUC19 vectors. Gene 33: 103119. 


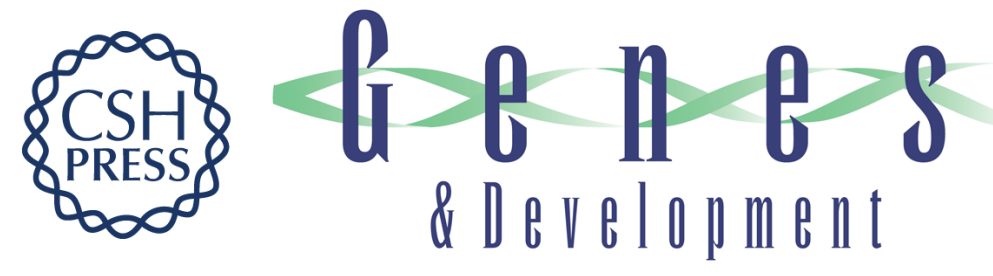

\section{Role of the sigma 70 subunit of RNA polymerase in transcriptional activation by activator protein PhoB in Escherichia coli.}

K Makino, M Amemura, S K Kim, et al.

Genes Dev. 1993, 7:

Access the most recent version at doi:10.1101/gad.7.1.149

References This article cites 34 articles, 12 of which can be accessed free at: http://genesdev.cshlp.org/content/7/1/149.full.html\#ref-list-1

License

Email Alerting

Receive free email alerts when new articles cite this article - sign up in the box at the

Service top right corner of the article or click here.

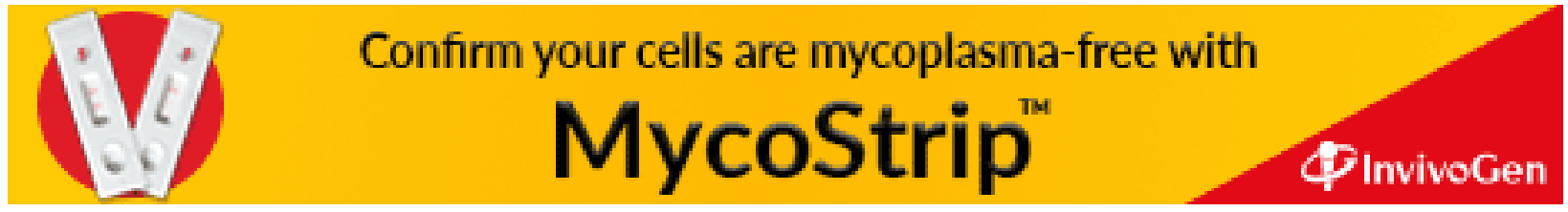

